\title{
Dampak Sertifikasi Terhadap Peningkatan Kualitas Mengajar Guru Di SD Negeri Kompleks IKIP Kota Makassar
}

\author{
Hasmiah \\ Manajemen Pendidikan Universitas Terbuka, Makassar \\ Email: hasmiah@ecampus.ut.ac.id
}

\begin{abstract}
This study aims to explain the Impact of Certification on Improving the Quality of Teaching Teachers in the SD Negeri Complex IKIP Makassar City. This type of research is explanatory with a quantitative approach. Whereas the effect test is done using simple linear regression. The results of the study obtained data that the number of civil servant teachers was 17 people 13 of whom were certified while 4 others were Non-permanent Teachers (GTT) and were already certified or around $81 \%$ of teachers who already had certification. Based on the calculation of correlation data between variables shows that there is a significant relationship between teacher certification with the quality of teaching teachers. Overall the direction of the relationship between the two variables is positive. this shows that the higher the value of teacher certification, the higher the value of the quality of teaching teachers. The magnitude of the correlation between the teacher certification variable and the variable of teaching quality is 0.816 . The magnitude of the effect between the teacher certification variables on the variable of the quality of teaching teachers is 0.678 or equal to $67.8 \%$. Then it can be concluded that there is an influence between teacher certification on the teaching quality of teachers.
\end{abstract}

Keywords: Certification; Quality of Teaching

\begin{abstract}
Abstrak. Penelitian ini bertujuan untuk menjelaskan Dampak Sertifikasi terhadap Peningkatan Kualitas Mengajar Guru di SD Negeri Kompleks IKIP Kota Makassar. Tipe penelitian ini adalah eksplanatory dengan pendekatan secara kuantitatif. Sedangkan uji pengaruh dilakukan dengan menggunakan regresi linier sederhana. Hasil penelitian diperoleh data bahwa jumlah guru PNS sebanyak 17 orang 13 diantaranya sudah bersertifikasi sedangkan 4 orang lainnya adalah Guru Tidak Tetap (GTT) dan sudah bersertifikasi atau sekitar $81 \%$ guru yang sudah memiliki sertifikasi. Berdasarkan data perhitungan korelasi antar variabel menunjukkan bahwa terdapat hubungan yang signifikan antara sertifikasi guru dengan kualitas mengajar guru. Secara keseluruhan arah hubungan antara kedua variabel tersebut positif. hal ini menunjukkan bahwa semakin tinggi nilai sertifikasi guru maka semakin tinggi pula nilai kualitas mengajar guru. Besarnya korelasi antara variabel sertifikasi guru dengan variabel kualitas mengajar adalah 0,816 . Besarnya pengaruh antara variabel sertifikasi guru terhadap variabel kualitas mengajar guru adalah 0,678 atau sama dengan 67,8\%. Maka dapat disimpulkan bahwa terdapat pengaruh antara sertifikasi guru terhadap kualitas mengajar guru.
\end{abstract}

Kata Kunci: Sertifikasi; Kualitas Mengajar

\section{PENDAHULUAN}

Perkembangan ilmu pengetahuan dan teknologi dewasa ini telah membawa perubahan dan pembaharuan berbagai aspek kehidupan manusia. Kualitas pendidikan sering menjadi isu sentral, hal mana yang sering menjadi sorotan adalah guru atau pendidik, walaupun disadari bahwa berbagai komponen turut mempengaruhi tinggi rendahnya kualitas pendidikan. Berbagai komponen yang turut mempengaruhi pendidikan yaitu: kurikulum, siswa, sarana atau fasillitas pendidikan dan guru sebagai pelaksana kurikulum. Oleh sebab itu, salah satu upaya yang dilakukan dalam peningkatan kualitas pendididikan adalah mengupayakan kinerja terciptanya kinerja guru atau tenaga kependidikan yang efisien, efektif, bersih dan berwibawa sehingga mampu melaksanakan tugas-tugas Negara khususnya di bidang kependidikan dalam pencapaian tujuan pendidikan nasional.

Undang-Undang Republik Indonesia Nomor 20 Tahun 2003 (2003: 7) menegaskan tentang tujuan pendidikan nasional yaitu: 
Berkembangnya potensi peserta didik agar menjadi manusia yang beriman dan bertaqwa kepada Tuhan Yang Maha Esa, berakhlak mulia, sehat, berilmu, cakap, kreatif, mandiri, dan menjadi warga negara yang demokratis serta bertanggung jawab. Manusia yang berakhlak mulia, yang memiliki moralitas tinggi sangat penting untuk dibangun melalui sebuah proses pendidikan, pembinaan pelatihan dan pemberdayaan SDM Indonesia secara berkelanjutan dan merata (Inanna, 2018).

Dalam mewujudkan tujuan pendidikan nasional di atas, diselenggarakan kegiatan pembelajaran, baik yang berlangsung di sekolah maupun di luar sekolah. Dalam kegiatan pembelajaran, salah satu komponen pendidikan yang sangat menentukan adalah guru, mengingat guru memiliki peran sebagai demonstrator, pengelola kelas, mediator dan fasilitator, serta evaluator. Peranan-peranan tersebut memberi konsekuensi pada perlunya guru mengenal tugas-tugasnya dalam kegiatan pembelajaran.

Fenomena rendahnya daya saing bangsa Indonesia di pasar global pada era persaingan kualitas menunjukkan bahwa pendidikan belum mampu menghasilkan sumber daya manusia yang berkualitas dan berdaya saing tinggi. Rendahnya daya saing bangsa ditunjukkan oleh indeks pengembangan manusia Indonesia yang berada pada peringkat 124, jauh berada di bawah peringkat negara tetangga Malaysia yang berada pada peringkat 61 dan Singapore berada pada peringkat 26 (Human Development Report 2013). Daya saing yang rendah dalam mendapatkan pekerjaan di pasar kerja nasional dan global diindikasikan oleh tingkat pengangguran yang masih tinggi, pada Februari 2012 mencapai 6,32 persen (BPS, 2012). Daya saing yang rendah suatu bangsa dapat disebabkan karena rendahnya mutu pendidikan dari bangsa tersebut, sehingga keluaran (output) pendidikan kurang mampu memenangkan persaingan di dunia ker ja dan dunia usaha. Keluaran pendidikan yang kurang berdaya saing dapat disebabkan karena kurang optimalnya kapasitas satuan-satuan pendidikan dalam mentranformasikan peserta didik untuk memperoleh nilai tambah. Pelaku utama dalam proses transformasi nilai tambah kepada peserta didik adalah guru. Oleh karena itu, guru dapat dikatakan sebagai pemegang peran yang sangat penting dan strategis dalam usaha meningkatkan mutu pendidikan di setiap satuan pendidikan. Berapa pun besarnya investasi yang ditanamkan untuk memperbaiki mutu pendidikan, tanpa kehadiran guru yang kompeten, profesional, bermartabat, dan sejahtera dapat dipastikan tidak akan tercapai tujuan yang diharapkan (UU No.14 Tahun 2005).

Guru sebagai salah satu komponen pendidikan sangat menetukan kualitas pendidikan melalui kegiatan pembelajaran. Salah satu subsistem yang menentukan keberhasilan suatu sistem pembelajaran adalah faktor guru (Rahmatullah \& Inanna, 2019). Oleh sebab itu, guru harus dibekali berbagai kemampuan dalam melaksanakan tugas, di samping rasa tanggung jawab atau pengabdian demi peningkatan kualitas kependidikan. Karena dalam sehari-hari, guru di sekolah selain sebagai pendidik juga sebagai pengajar. Sebagai pengajar, guru setidak-tidaknya harus menguasai bahan yang diajarkan dan mempunyai keterampilan dalam mengajarkannya. Untuk merespon perkembangan IPTEK, guru diharapkan mampu menguasai model, metode dan media pembelajaran sehingga dapat diaplikasikan dalam proses pembelajaran dikelas, sebagai wujud profesionalitasnya (Ramli, Rahmatullah, Inanna, \& Dangnga, 2019). Bahan yang harus diajarkan tercermin dalam kurikulum, sedangkan cara mengajarkan bahan tercermin atau berkaitan dengan proses pembelajaran.

Proses pembelajaran terjadi manakala ada interaksi antara guru dengan siswa, atau siswa dengan siswa. Dalam interaksi tersebut, guru menerapkan fungsi sebagai pengajar atau pemimpin belajar atau fasilitator belajar, sedangkan siswa pelajar atau individu yang belajar. Keterpaduan fungsi tersebut mengacu pada tujuan yang sama yakni mengembangkan potensi siswa yang secara opersional tercermin dalam tujuan pendidikan dan tujuan pengajaran. Jika gurunya berkualitas baik, maka pendidikan juga akan baik, jika tindakan para guru dari hari ke hari bertambah baik, maka akan menjadi lebih baik pulalah keadaan dunia pendidikan, khususnya dalam mencetak generasi yang terdidik (Farmawati, Ramli, \& Rahmatullah, 2019). Kegiatan pembelajaran sebagai suatu proses yang memerlukan keterlibatan dua belah pihak. Namun demikian, dengan fungsi dan peran yang diemban oleh seorang guru memberi konsekuensi perlunya kemampuan dalam kegiatan pengajaran atau memiliki keterampilan mengajar. Keterampilan mengajar mulai dari membuka sampai pada menutup pelajaran. Hal 
ini sesuai pendapat Sardiman (1994:192) bahwa "sistem pengajaran menempatkan guru pada tempat yang sangat penting dalam kegiatan pembelajaran sekaligus memberi konsekuensi pada perlunya keterampilan dalam pelaksanaan pembelajaran". Hal senada di kemukakan oleh Roestiyah (1998:1) bahwa "dalam kegiatan pembelajaran, guru harus memiliki kemampuan dalam menerapakan strategi agar siswa dapat belajar secara efektif dan efesien".

Salah satu keterampilan mengajar yang sangat perlu dimiliki guru adalah keterampilan mengelola kelas. Hal ini dimaksudkan agar kondisi belajar mengajar dapat berlangsung optimal dan mengembalikan bila terjadi gangguan dalam proses belajar mengajar, seperti penghentian tingkah laku siswa yang menyelewengkan perhatian dalam kelas, pemberian ganjaran bagi ketetapan waktu penyelesaian tugas oleh siswa, atau penetapan norma kelompok yang produktif. Hal ini berarti bahwa salah satu faktor yang menentukan optimalnya kegiatan belajar mengajar adalah kemampuan guru dalam mengelola kelas secara profesional.

Kinerja guru mempunyai klasifikasi tertentu. Kinerja guru dapat dilihat dan diukur berdasarkan klasifikasi/kriteria kompetensi yang harus dimiliki setiap guru. Berkaitan dengan kinerja guru, wujud prilaku yang dimaksud adalah kegiatan guru dalam proses pembelajaran yaitu bagaimana seorang guru merencanakan pembelajaran, melaksanakan proses pembelajaran dan menilai hasil pembelajaran.

Seorang guru yang memiliki kinerja yang tinggi ditunjukkan dengan keprofesionalannya dalam menjalankan profesinya, menurut Sayud dalam Soetjipto (2004:153) kinerja guru diukur melalui: "Penguasaan bahan ajar, pemahaman karakteristik siswa, evaluasi pembelajaran dan kepribadian".

Berdasarkan latar belakang tersebut di atas, maka masalah yang diajukan melalui penelitian ini adalah"apakah sertifikasi berdampak terhadap peningkatan kualitas mengajar guru di SD Negeri Kompleks IKIP di Kota Makassar?'

\section{METODE PENELITIAN}

Jenis penelitian yang digunakan dalam penelitian ini yaitu penelitian kuantitatif dimana pendekatan analisis menekankan analisisnya pada data-data numerikal (angka) yang diolah dengan metode statistika (Azwar, 2011: 5).
Data-data numerikal yang dimaksud adalah data-data yang berupa angka-angka sebagai alat untuk menemukan keterangan atau informasi mengenai apa yang ingin diketahui dalam penelitian ini, kemudian hasil dari data numerikal tersebut dianalis dengan menggunakan teknik statistik.

Penelitian bertujuan untuk mengetahui dampak sertifikasi guru (penelitian evaluatif) dalam rangka memberikan informasi akurat sebagai dasar kebijakan selanjutnya untuk meningkatkan kualitas mengajar guru di sekolah dasar. Penelitian dilakukan di Kota Makassar.

Dalam penelitian ini ada dua variabel, yaitu variabel bebas yaitu sertifikasi (X) dan variabel terikat yaitu kualitas mengajar guru (Y). Deskrispsi Variabel dan Indikator Penelitian dampak sertifikasi guru terhadap peningkatan kualitas guru sekolah dasar menfokuskan pengamatan pada keluaran pada guru SD Negeri Kompleks IKIP yang sudah bersertifikasi. Karenanya variabel dan indikator penelitian disusun berdasarkan Standar Pendidikan Nasional untuk mengukur tingkat sumbangsi dan peran guru yang telah disertifikasi terhadap peningkatan kualitas mengajar pada sekolah dasar. Dari delapan SNP, dipilih beberapa standar yang memiliki keterkaitan langsung, atau dimungkinkan guru dapat berperan, yaitu standar pengelolaan, standar proses pembelajaran, standar pendidik dan tenaga kependidikan, serta sarana prasrana. Secara rinci sub variabel penelitian mencakup: pertama keterlibatan guru sertifikasi pada perencanaan pembelajaran.

Penelitian ini merupakan jenis penelitian kuantitatif yang bertujuan mencari korelasi (pengaruh) variabel bebas $(\mathrm{X})$ terhadap variabel terikat (Y). dimana variable bebas yakni seritifikasi dan variabel terikat yakni kualitas mengajar guru di SD Negeri Kompleks IKIP di Kota Makassar, dengan demikian, model persamaan regresi linear sebagai:

Dimana:

$$
\mathrm{Y}=\mathrm{a}+\mathrm{bX} \mathrm{X}_{1}
$$

$\mathrm{Y}=$ Kualitas Mengajar Guru (Variabel Terikat)

$\mathrm{X}=$ Sertifikasi Guru (Variabel Bebas)

Populasi penelitian ini berjumlah di bawah 100 orang, yaitu hanya 21 orang sehingga semua populasi menjadi sampel penelitian.

Pengumpulan data sekunder yaitu teknik pengumpulan data dengan memanfaatkan sumber daya yang telah ada dilapangan yang 
kemudian digunakan untuk melengkapai data penelitian sesuai dengan kebutuhan penelitian Basrah,2014). Pengumpulan data sekunder dalam penelitian ini bias didapat dokumentasi yang ada di sekolah, seperti daftar hadir guru, laporan gaji guru, laporan kegiatan guru dan sebagainya.

Teknik analisis data yang digunakan dalam penelitian ini adalah analisis statistic deskriptif untuk menghitung pengaruh antara variabel (Arikunto, 2006: 314). Tehnik analisis data yang digunakan dalam penelitian ini adalah analisis regresi, untuk mengetahui bagaimana variabel dependen dapat diprediksi melalui variabel independen (Sugiyono, 2009: 153). Analisis regresi dapat digunakan untuk memutuskan variabel dependen ( $\mathrm{Y}=$ kualitas mengajar guru) mengalami kenaikan atau penurunan ketika variabel independen ( $\mathrm{X}=$ sertifikasi guru) mengalami kenaikan atau penurunan.

\section{HASIL DAN PEMBAHASAN}

Adapun data keadaan Pendidik dan Tenaga Kependidikan serta Peserta Didik yang ada sekitar 21 orang guru tetap PNS 17 orang dan 4 orang guru Non PNS atau Guru Tidak Tetap (GTT) jadi jumlah guru seluruhnya sebanyak. Jumlah guru tersebut sekitar 17 orang guru 13 diantaranya guru PNS yang sudah bersertifikasi pendidik dan 4 diantaranya GTT yang sudah memiliki sertifikasi pendidik atau sekitar $81 \%$ guru yang ada di SDN Kompleks IKIP Kota Makassar sudah bersertifikasi.

Sedangkan sarana dan prasarana yang dimiliki sekolah yang terdiri ruang kelas sebanyak 12 ruang, ruang laboratorium 1 ruang dan ruang perpustakaan sebanyak 1 ruang.

Data mengenai jumlah siswa per rombongan belajar berdasarkan kelas dan jenis kelamin yang ada di Sekolah Dasar Negeri Kompleks IKIP Makassar menunjukkan bahwa jumlah siswa laki-laki sebanyak 274 orang sedangkan jumlah siswa perempuan sebanyak 249 dari jumlah keseluruhan siswa sebanyak 523 orang siswa dari 6 rombongan belajar.

Berdasarkan data yang di peroleh dari SDN Kompleks IKIP Makassar, diketahui jumlah keseluruhan guru adalah 21 orang. Adapun jumlah populasi dalam pengamatan ini adalah guru lulus sertifikasi hanya melalui jalur fortofolio dan jalur PLPG yaitu sebanyak 17 orang yang memiliki presentase $81 \%$ dari jumlah keseluruhan guru. Presentase yang tergolong sangat tinggi. Sedangkan belum sertifikasi sebanyak 4 orang dari keseluruhan guru yang ada yakni sebesar $19 \%$. Hal ini karena keyakinan bahwa guru tersertifikasi akan memiliki mutu yang lebih baik dalam proses pembelajaran. Guru tersertifikasi adalah guru yang sudah cukup mampu untuk melaksanakan dan menguasai empat kompetensi mendasar yang harus dimiliki. Sehingga mampu merubah peserta didiknya menjadi manusia yang benar-benar siap menghadapi tantangan zaman baik di bidang ilmu pengetahuan teknologi dan pemahaman atas nilai-nilai etika dan moral. Akan tetapi inilah kenyataan yang terjadi, sejak di berlakukannya sertifikasi guru pada tahun 2007, hanya 4 orang guru saja yang belum tersertifikasi itupun mereka lulus Sarjana pada tahun 2017. Selanjutnya sangat di harapkan dalam waktu singkat kedepanya jumlah guru tersertifikasi meningkat dengan catatan bahwa proses sertifikasi mencetuskan guru yang kualitas kinerjanya terjamin. Perlu penanganan serius dari pihak Perguruan Tinggi penyelenggara sertifikasi untuk lebih cermat dan konsekuen dalam melakukan seleksi guru tersertifikasi.

SDN Kompleks IKIP Makassar memiliki tenaga kependidikan yang terdiri dari seorang kepala sekolah, 17 orang guru tetap, dan 4 orang guru tidak tetap.

Ketenagaan menurut Status Kepegawaian, Jabatan, Golongan dan Pendidikan Terakhir menelaah penyebab mendasar berhasilnya sertifikasi dalam melahirkan guru yang berkompeten dan kualitas mengajar yang baik di SDN Kompleks IKIP Makassar. Melalui data pendidikan terakhir guru tersertifikasi sampai saat ini masih ada yang hanya lulusan SMA dan D2. Hanya 2 orang guru saja yang sudah memenuhi persyaratan utama yaitu minimal memiliki ijasah akademik atau kualifikasi akademik minimal S-1 atau D4 namun juga sudah ada 2 orang guru yang sudah memiliki kualifikasi S2. Hal ini sangat menunjang proses belajar mengajar guru dan pengalaman guru, pendidikan guru tersertifikasi bahkan kalah dengan pendidikan guru tidak tetap.

Pemerintah mengeluarkan peraturan mengenai syarat utama seorang guru mengajukan keinginanya mendapat sertifikat pendidik masih saja terjadi penyimpangan dalam prosesnya. Untuk lebih jelasnya permasalahan ini, kita perlu mengetahui urutan kriteria calon peserta sertifikasi sebagai berikut 
yaitu (1) masa kerja, (2) usia, (3) golongan (bagi PNS), (4) tugas tambahan, (5) prestasi kerja, dan (6) beban mengajar. Hal ini juga menjadi bahan pertimbangan guru tersebut di luluskan dalam ujian sertifikasi. Akan tetapi, jika kita berkaca kembali pada program pemerintah dalam kesetaraan guru yang mewajibkan pendidikan terakhir seorang guru Sekolah Dasar adalah S1 atau D1V maka timbul lagi pertanyaan apakah kesetaraan itu dilakukan secara merata di seluruh wilayah NKRI?. Bahkan sekarang bukti nyata yang terjadi masih ada guru yang belum berpendidikan S1 atau D IV. Sebaiknya pemerintah lebih peka lagi dalam hal ini, meninjau kembali hasil dari program yang di jalankan. Apakah sudah merata atau tidak, harus di data secara menyeluruh sampai ke bagian pelosok sekolah-pun selama masih dalam koridor wilayah NKRI.

Selain itu, pihak guru juga harus memiliki kesadaran dalam meningkatkan kualitasnya melalui perbaikan jenjang pendidikan yang dilalui. Walaupun tujuanya untuk memiliki ijazah sesuai standar yang berlaku. Akan tetapi, harus di ingat kembali niat utama sebelum tujuan itu tercapai adalah bagaimana menjadi seorang pendidik yang professional. Ini menyangkut kualitas generasi pembelajar, kualitas anak bangsa. Jadi seorang guru harus menanamkan prinsip seperti dalam agama kita "jika belajar itu adalah ibadah, maka berprestasi itu adalah dakwah". Seorang guru harus mampu berprestasi sebagai bekal dakwah kepada peserta didiknya.

Pada dasarnya peningkatan kualitas pendidikan sangat ditentukan oleh oprasionalisasi managemen di tingkat sekolah, peran utama dalam meningkatkan roda managemen sekolah terletak pada kepala sekolah (Wahyosumidjo, 2011:440). Keberhasilan penddikan disekolah sangat ditentukan oleh keberhasilan kepala sekolah dalam mengelola tenaga kependidikan yang tersedia disekolahnya. Keberhasilan kepala sekolah tersebut sangat berkaitan dengan kepemimpinan dan managemennya meningkatkan kinerja komponen didalamnya. Komponen yang sangat menentukan mutu pendidikan tersebut adalah kinerja guru yakni kualitas mengajar guru-guru yang ada dalam merancang proses belajar mengajar di kelas dengan baik dan kondusif.

Berdasarkan permasalahan dan analisis data dengan menggunakan koefisien regresi diperoleh persamaan yaitu, $\hat{Y}=0,452+2,304$ $X$, yang berarti bahwa nilai konstanta sebesar 0,452 adalah besar/tingginya guru yang bersertifikasi tanpa memperhatikan tinggi rendahnya kualitas mengajar guru, sedangkan nilai koefisien regresi sebesar 2,304X yang berarti bahwa setiap terjadi peningkatan nilai guru yang bersertifikasi sebesar 1, maka akan terjadi peningkatan kualitas mengajar guru sebesar 2,304.

Sedangkan hasil analisis tersebut maka diperoleh nilai dari koefesien korelasi (r) sebesar 0,823 yang berarti bahwa hubungan antara sertifikasi guru dengan kualitas mengajar tinggi. Sedangkan koefisien determinasi $\left(\mathrm{r}^{2}\right)$ sebesar 0,678 atau $67,8 \%$ yang berarti bahwa pengaruh sertifikasi guru terhadap kualitas mengajar SD Negeri Kompleks IKIP Kota Makassar adalah sebesar 67,8\%, sedangkan sisanya $32,2 \%\left(100 \%-r^{2}\right)$ ditentukan oleh faktor lain yang tidak termasuk dalam penelitian ini.

Dari hasil analisis tersebut maka diperoleh nilai signifikan sebesar 0,018 dimana nilai signifikan tersebut lebih kecil dari nilai alpha yaitu 0,05 yang berarti bahwa sertifikasi guru berpengaruh signifikan terhadap kualitas mengajar guru di SD Negeri Kompleks IKIP Kota Makassar. Sehingga hipotesis yang diajukan yakni "Diduga bahwa sertifikasi guru berpengaruh signifikan terhadap kualitas mengajar guru dinyatakan "diterima".

\section{SIMPULAN DAN SARAN \\ Kesimpulan}

Berdasarkan pembahasan permasalahan pada penelitian yang telah dilakukan,maka dapat diambil kesimpulan sebagai berikut:

1. Berdasarkan hasil penelitian yang dilakukan, dapat disimpulkan bahwa terdapat pengaruh antara sertifikasi guru terhadap kualitas mengajar guru, artinya Ho ditolak dan $\mathrm{Hi}$ diterima. Hasil ini didapatkan melalui pengisian kuesioner yang kemudian datanya diolah menggunakan SPSS serta ditambah dengan hasil wawancara terhadap 21 responden.

2. Hasil perhitungan yang menunjukkan bahwa adanya pengaruh yang tinggi antara variabel sertifikasi guru terhadap kualitas mengajar guru. Pengaruh kedua variabel yang diteliti ini menunjukkan nilai sebesar 0,678 atau sebesar $67,8 \%$. Angka tersebut mempunyai arti bahwa $67,8 \%$ variabilitas kualitas 
mengajar guru yang terjadi dapat dijelaskan dengan variabel sertifikasi guru.

3. Adapun hasil korelasi antar variabel menunjukkan bahwa kedua variabel yang diteliti memiliki hubungan yang positif yaitu sebesar 0,823 dengan tingkat signifikansi 0,000 semakin banyaknya guru yang bersertifikai maka akan berdampak pada tingginya tingkat kualitas mengajar guru.

\section{Saran}

Berdasarkan simpulan diuraikan di atas, maka saran dari penulis adalah:

1. Menjadi seorang guru adalah pekerjaan yang mulia karena melalui guru anak-anak mendapatkan pengetahuan diluar lingkungan keluarganya. Oleh sebab itu, diharapkan bagi para guru agar dapat selalu mencintai profesinya agar dapat menularkan ilmu-ilmu dan kreatifitas kepada murid sehingga kemajuan pendidikan nasional dapat terwujud.

2. Sertifikasi guru adalah suatu program pendidikan yang telah lama dinanti tenaga pendidik untuk membantu kesejahteraan guru karena pada kenyataannya memang kesejahteraan guru belum terjamin sebelum adanya sertifikasi guru. Kesejahteraan yang kini telah terjamin diharapkan dapat dibarengi dengan peningkatan kualitas mengajar para pendidik agar pendidikan di Indonesia semakin baik. Menggunakan tiap kesempatan yang ada sebagai bahan untuk mengembangkan diri, meningkatkan kedisiplinan, dan bertanggungjawab terhadap profesi guru adalah salah satu cara untuk meningkatkan kualitas diri sebagai tenaga pendidik.

3. Salah satu tujuan utama diadakannya program sertifikasi adalah meningkatkan mutu pendidik, maka pemerintah juga harus memberikan konsentrasi pada perbaikan mutu pendidik dengan mengawasi kinerja setiap guru yang telah tersertifikasi agar semakin baik dalam mengajar. Memberikan kesempatan bagi guru yang belum tersertifikasi agar dapat menunjukan kualitas dirinya sebagai tenaga profesional melalui kebijakan- kebijakan tertentu.

Mendorong tenaga pendidik dan pemerintah dalam meningkatkan pendidikan nasional adalah tugas bersama bagi masyarakat. Memberikan dukungan moral bagi guru agar dapat meningaktkan mutu sebagai pendidik, menunjukkan dukungan dan memberikan tanggapan dengan cara yang baik pada setiap kebijakan yang akan diputuskan untuk kebaikan bersama.

\section{DAFTAR RUJUKAN}

Acuan Badan Pusat Statistik. (2012). Berita Resmi Statistik No. 33/05/Th. XV, 7 Mei 2012. Keadaan Ketenagakerjaan Pebruari 2012.

Baruningsih, Palupi. (2011). Pengaruh Sertifikasi Profesi Guru Terhadap Kinerja Guru Akuntansi di Smk SeKabupaten Sragen. Fakultas Ekonomi Universitas Negeri Semarang. Semarang.

Basrah, Hendryadi. (2014). Metode Pengumpulan Data.

Http://teorionline.wordpress.com. Diunduh tanggal 27 Februari 2014.

Burhanuddin, Afid. (2013). Pengumpulan Data dan Instrumen Penelitian. Http:// afidburhanuddin.

wordpress.Com/2013/05/21/pengumpula n-data-aninstrument-penelitian. Diunduh tanggal 15 Januari 2014.

Depdiknas. (2013). Sertifikasi Guru dalam Jabatan Tahun 2013. Http://psg15.um.ac.id/leafletsertifikasi.pdf. Diunduh tanggal 19 Oktober 2014.

Fahmi, Teuku. (2014). Perbedaan Tingkat Perceived Risk, Fear Of Crime dan Mekanisme Coping pada Masyarakat Yang Beraktivitas di Wilayah Rawan Tindak Kejahatan. Lampung. Universitas Lampung. Gunawan.

Farmawati, E., Ramli, A., \& Rahmatullah, R. (2019). Faktor-Faktor Yang Memengaruhi Kinerja Guru Ekonomi Pada SMA Negeri Di Kota Makassar. JEKPEND: Jurnal Ekonomi Dan Pendidikan, 1(2), 23-29.

Inanna, I. (2018). Peran Pendidikan Dalam Membangun Karakter Bangsa Yang Bermoral. JEKPEND" Jurnal Ekonomi Dan Pendidikan", 1(1), 27-33.

Kemdikbud. (2013). Panduan Penetapan Peserta Program Sertifikasi Tahun 2013. Hhtp://bpsdmpk.kemdikbud.go.id/pdf. Diunduh tanggal 15 Januari 2014.

Lestari, Sri. (2010). Pengaruh Program Sertifikasi Guru terhadap Kinerja Guru di MTs Negeri Mlinjon Trucuk Klaten. Yogyakarta.

Poliyama Widyapustaka. Hasibuan, Indah Julita. (2015). Pengaruh Rasa Takut (Fear) Masyarakat Terhadap Mekanisme 
Coping Terkait dengan Maraknya Kasus Kekerasan Seksual Terhadap Anak di Kecamatan Pringsewu, Kabupaten Pringsewu. Lampung.

Prasetyo, Bambang dan Lina Miftahul Jannah. (2012). Metode Penelitian Kuantitatif: Teori dan Aplikasi. Jakarta. Rajawali Pers. Rahmatullah, R., \& Inanna, I. (2019). Pelatihan Penulisan Penelitian Tindakan Kelas Bagi Guru. Jurnal Dedikasi Masyarakat, 3(1), 19-25.

Ramli, A., Rahmatullah, R., Inanna, I., \& Dangnga, T. (2019). Peran media dalam meningkatkan efektivitas belajar.

Prosiding Seminar Nasional Lembaga Pengabdian Kepada Masyarakat, 5-7. Retrieved from https://ojs.unm.ac.id/semnaslpm/article/do wnload/7649/4429

Sakwati, Monalia. (2015). Pengaruh Partisipasi Masyarakat terhadap Keberhasilan Rural Infrastructure Support To Program Pemberdayaan Masyarakat (RIS-PNPM) Mandiri. Lampung. Universitas Lampung.

Saniyah. (2008). Motivasi Guru dalam Mengikuti Program Sertifikasi Guru di Madrasah Aliyah Negeri (MAN) Model Bangkalan. Malang. Universitas Islam Negeri Malang.

Sarwono, Jonathan. (2006). Analisis Data Penelitian Menggunakan SPSS Edisi 1. Yogyakarta. ANDI Singarimbun,

Suryati, Wawat. (2011). Profesi Kependidikan. Bandar Lampung. Lembaga Penerbit STKIP Bandar Lampung.

Suwarto, Tok. (2014). Kompetensi Profesional Guru Pasca-sertifikasi Masih Lemah. Pikiran. 